\title{
Politics, Ideology and Print Media: A CDA of Newspapers' Headlines
}

\author{
Muhammad Akbar Sajid ${ }^{1}$, Behzad Anwar ${ }^{2 *}$, Muhammad \\ Ashraf $^{3}$ \\ ${ }^{1,3}$ National University of Modern Languages, Multan, Pakistan \\ ${ }^{2}$ University of Gujrat, Gujrat, Pakistan \\ *Corresponding author: behzad.anwar@uog.edu.pk
}

\begin{abstract}
The present study critically decodes the headlines of Pakistani-English newspapers to locate linguistic spin employing different political ideologies in the desired manner by the controlling groups. The headlines which appeared in the daily 'Dawn' and 'Nation' newspapers during the year 2014 have been categorised into various themes such as theme of politics, nationalism, internationalism, terrorism, and economics but in the present study, the researchers have only focused on the headlines carrying the topic of politics. In this regard, two headlines from each newspaper about the theme of politics have been randomly selected and analysed by employing Dijk's (2006) analytical framework of critical discourse analysis (CDA). Additionally, the existing model of Dijk has been amended in accordance with the nature of the existing data. Therefore, four headlines from each newspaper randomly selected carrying political themes have been analysed to explore how different discursive techniques employed in the coinage of newspaper headlines (mis)represent the same political event differently. The researchers have investigated the print media coverage of the same event in both the newspapers' headlines to lay bare how different discursive techniques are employed to represent the same news item by different ideological groups to propagate desired political ideologies. The findings of the study highlight that different discursive moves are used by print media to represent the same event differently to propagate desired ideology. That is how print media discourses represent certain people belonging to in/out-groups.
\end{abstract}

Keywords: headlines, Critical Discourse Analysis (CDA), ideology, politicized language

\section{Introduction}

A long way from being a very objective reflection of factual events, newspaper headlines construct truth in a way similar to underlying ideologies of the presenters and their supposed target audience. As a result, the same event could be 
represented differently by various newspapers to propagate the desired ideology (Wang, 1993; Fang, 2001).

In Pakistan, English newspapers usually have a significant influence on the government and people. Many newspapers in local or vernacular languages are published in Pakistan but those newspapers do not have much influence on subjects. Newspapers in different languages like Sindhi, Pashtu, Saraiki and Punjabi are published on daily or weekly basis in Pakistan, but these are ignored because these languages are not the languages of the powerful class in Pakistan. English is the language which is widely spoken and is influential in Pakistan as it is the language of the elite class. It is not surprising that English is the marker of elitist social status and the most desired skill for lucrative employment in the country (Rahman, 1996, 2007). Currently fourteen English newspapers are published through different mediums from different areas of Pakistan including Business Recorder (Islamabad, Karachi and Lahore, started in 1965), Daily Times (Lahore, Karachi and Islamabad, started in 2002), Dawn (Karachi, Lahore and Islamabad, started in 1947), The Friday Times (Lahore, started in 1989), The Frontier Post (Peshawar, Quetta and Lahore, started in 1985), The Nation (Lahore, Karachi and Islamabad), The News International (Islamabad, Karachi, Lahore and London, started in 1991), Pakistan Observer (Islamabad, Karachi, Peshawar, Lahore, Muzaffarabad and Quetta, started in 1988), The Post ( Lahore, Karachi and Islamabad, started in 2005), The Regional Times of Sindh (Karachi and Hyderabad), The Star ( Karachi, started in 1951), The Statesman (Peshawar, started in 2002), Pakistan Today (Lahore, Karachi and Islamabad, started in 2010) and The Lahore Times (Lahore, started in 2011, available only online). This study is an attempt to highlight the techniques by which different English newspapers characterize the ideology of their target readership through the use of different discursive techniques in the coinage of front-page headlines, while adopting the Dijk's (2006) method of critical discourse analysis. Additionally, the data has also been analysed qualitatively and quantitatively.

\section{Significance of Headlines}

Ogilvy (2006) asserts that headlines are best site for ideological investment and are considered as one of the most important genres of newspapers as they can capture the attention of specific readership easily to provide them an overview of the social construction of ideology in a desired manner. Headlines play an important role in orienting the readers' interpretation of a particular event. Ungrammaticality is a prominent feature of newspapers' headlines. They capture a story in the fewest 
possible words. As Abastado (1980, p.149) argues that "headlines encapsulate not only the content but the orientation."

\section{Critical Discourse Analysis}

Fairclough \& Wodak (1997) regard language as a social practice. According to them, discourse is language in action in society. Describing discourse as a social practice implies a dialectical relationship between a particular discursive event and the situation(s), institution(s), and social structure(s), which frame it: the discursive event is shaped by them, but it also shapes them. That is, discourse is socially constitutive as well as socially conditioned. CDA, is a post-mortem of language to explore the deeper meanings embedded in different layers of language. Moreover, it can also reveal biases of new reporter/controlling ideological group to maintain power and construct reality in a desired manner.

\section{Discursive Techniques Used in Print Media}

There is power within and behind print media discourses. Print media on one hand serves the purpose of controlling ideological groups and on the other hand highly politicized language (mis)represent an event to propagate desired ideology. Usually, it is observed that in order to disseminate different ideologies to the readers, different discursive techniques are used by print media. These discursive techniques are used as persuasive tools to disseminate particular ideology to the target readership (Phillips et al., 2004). CDA focuses on studying or exploring different discursive techniques, employed by a powerful group or community to subjugate the powerless with the help of certain linguistic practices. The group, which is aware of these discursive techniques, subjugates those who are unaware of these. Hence, they shape the mindset of the people and maintain their dominance and hegemony.

\section{Research Question}

The controlling research question for the study is:

How are political events represented discursively by Pakistani English newspapers, The Daily Dawn and The Daily Nation to disseminate desired political ideologies? 


\section{Literature Review}

Ulum (2016) carried out a research based on newspaper headlines representing Syrian refugees. It is a cross-cultural study done with an aim to investigate ideologies spread through newspaper headlines, through the lens of CDA. He concludes that the western editors present the issue in terms of how Europe can withstand such a high flow of Syrians into the union, in contrast to the Turkish media which highlight the issue by glossing the hard conditions in which these refugees are, on their way to Europe. Gopang, Faraz \& Bughio (2015) have compared the newspaper headlines in a comparative CDA analysis of Sindhi, Urdu and English newspapers presenting the budget 2013-14. They conclude that ideological representations are made according to the society, while employing a number of discursive strategies and themes. The editors of newspapers employ loaded vocabulary in order to propagate political ideology. Alfangca (2015) carried out a research based on the representation of MH370 flight incident in the newspaper headlines. Her study reveals the very fact that ideologies can even be disseminated through transitivity analysis while making use of loaded lexical items. Bonyadi \& Samuel (2013), in their analysis of headlines in newspaper editorials, reveal that the editors had a very subjective attitude toward the topic. Javed \& Mehmood (2011) on the topic of "A CDA of the News Headlines of Budget of Pakistan FY 2011-2012", Sajid (2013) on the topic of "CDA of News Headlines about Imran Khan's Peace March towards Waziristan". In these researches, the researchers have tried to locate different themes embedded in English and Urdu newspapers headlines and articles, grammaticality and ungrammaticality of headlines and ideological function behind the grammatical deviation, representation of budget speech in the headlines of national and international newspapers according to social and political interests and representation of president of Tehreek-e-Insaf's march toward Waziristan in national and international print media. The present research is different from the mentioned researches as it critically analyses the coverage of same event through different print media groups.

\section{Research Methodology}

Four headlines (two from each newspaper) carrying political ideology regarding the same event in The Daily Dawn and The Daily Nation from the months of August and September 2014 have been randomly selected to analyse by applying the amended model of Dijk (2006). The present study adheres to the notion that whatever is written or said about the world is actually articulated from a particular ideological perspective (Fowler, 1991). CDA makes itself a compulsory choice for the analysis of newspaper language, particularly headlines. It is the choice of the 
linguistic items that makes evident the underlying ideologies of newspapers, which otherwise may not always be surfaced. The methodological framework for the present study has been discussed in detail in the following section.

\section{Theoretical Framework}

Dijk (2006) in his work, "Politics, Ideology and Discourse", proposes a research model to analyse print media discourses. He describes that print media discourses are more suitable to propagate different types of ideologies. Moreover, he is of the view that in political discourses different linguistic spins are used to politicize the event to propagate what is desired by the ideological controlling groups. Moreover, he talks about an important factor about political discourses that is they carry two types of power i.e. power within discourses and power behind discourses.

\section{CDA of Media Discourse}

CDA is applied in different domains for a detailed analysis of both texts i.e. written and spoken. Media discourse is analysed in relation to different social aspects like political, geographical and historical context. He proposes an effective and result oriented socio-cognitive framework to analyse discourses of print media. According to him, media discourse represents the assumptions of ideological group of media depending on their cultural, political and social background (Dijk, 1998). However, it is important to know that media discourse cannot be interpreted easily; even simple texts (headlines) carry different implicit and explicit ideologies.

\section{Categories of Ideological Discourse Analysis}

Dijk's (2006) model consists of the following analytical categories:

- Actor description (meaning): Based on the ideologies, actors are described in a positive/negative way.

- Authority: Mentioning authorities in remarks to support one's claims.

- Categorization: When people are assigned in people to different groups.

- Consensus: Agreement and solidarity among members of a group or society.

- Disclaimer: Idea are presented as positive and suddenly rejected in second part of sentence with the help of different words such as "but".

- Evidentiality: Support of ideas or statement with the help of facts.

- Hyperbole: When a statement or any event is exaggerated. 
- Implication: Telling any information which is not told in the sentence apparently.

- Irony: A trope that involves incongruity between what is expected and what occurs Or Saying something and meaning something else.

- Lexicalization: It is a discursive technique for the representation of others through the use of different words in statement or discourse.

- National Self Glorification: Glorification of one's country by telling positive things about her in statements.

- Number Game: Use of numbers, facts and figures to make statement concrete.

- Polarization: Representation of persons and departments with good attributions of US to make "In group" and representation in bad way of THEM to make "out group".

- Presupposition: Pre-occupation of mind about anything, person and incident.

- Vagueness: Un-clarity and ambiguity about anything or issue.

- Victimization: Representation of Others by telling bad stories about them.

\section{Data Analysis and CDA of Newspapers Headlines}

This section deals with critical discourse analysis of the selected front page main headlines of the mentioned newspapers regarding the representation of political events. It shows that how same political themes is represented differently by employing various discursive techniques by the two newspapers.

Dijk (2008) believes that print media discourses act like a prism, either to construct reality or to distort reality as designed by some ideological group. Each newspaper serves as a sight of ideological investment to shape the mindset of target readership accordingly.

\section{Analysis and Discussion: Same Event, Different Representations}

\section{Theme of Politics}

The headlines published in the daily "The Nation" and "The Daily Dawn" on $29^{\text {th }}$ September 2014 have been analysed below employing Dijk's (2006) model to locate ideological underpinnings with the help of different discursive techniques. 


\section{Headlines:}

\section{H.D1: Imran vows to hold rallies in all big cities}

\section{H.N1: Imran Khan steals Punjab's heart}

The context that surrounds the two headlines is about the sit in staged by Imran Khan and its print media coverage in the Dawn newspaper goes like this; Imran vows to hold rallies in all big cities. Above mentioned newspaper headlines are coined after a successful rally in Lahore. Two different newspapers published the same news items with different ideological underpinning by employing different discursive techniques according to the target readership to propagate desired ideologies. To represent a different representation of facts, a news reporter reconstructs reality in a desired manner according to ideologies of the presenters and their target readership (Fowler, 1991). As a result, the same news event is represented differently by using different discursive techniques in different newspaper headlines depending on the desired ideologies of the newspaper(s) (Fang, 2001).

\section{H.D1: Imran vows to hold rallies in all big cities $\left(29^{\text {th }}\right.$ September 2014$)$}

The headline under discussion finds coverage in "The Daily Dawn" carrying political theme. Different discursive techniques are used to propagate political ideology in this headline as can be seen below:

Actor: Imran

Categorization: all big cities

Lexicalization: vows

Presupposition: hold rallies

Preposition: to, in

This headline illustrates that Imran regards his protest sessions or rallies against the government to enlighten the people as his religious obligation. Merriam-Webster dictionary (2015) defines, the lexical item, the verb "vow" as, "Serious promise made by someone to do something for the benefit of others."

To represent the same event differently the two newspapers have employed different ideological discursive techniques for example, in the first headline there is the use of lexicalization in the form of word vows. As far as the connotation of the word vows are concerned, they are like this; a solemn promise made by someone to carry out some sacred duty. So, here actor, Imran Khan has been represented positively because according to the headline of this newspaper, Imran considers it his moral obligation or a kind of religious duty to hold rallies in all the big cities of 
Pakistan in order to enlighten the people about the corrupt political scenario prevailing everywhere in the country. In this regard, Imran has been represented as a preacher or a spiritual leader who has fully internalized that it is his duty to lead the people to the right direction. Moreover, there is the use of present tense which is often used for indefinite concept of time and for universal truths as well. So, the use of present tense in the form of vows implies that Imran's struggle in the form of holding rallies to enlighten the people against the corrupt political scenario is not time bound. It also implies his intensity of feelings and determination that he has taken an initiative which will never come to an end. Moreover, the use of expression all the big cities implies Imran's determination and vision that does not seem belonging to a particular province or a city as is usually alleged by different political parties that he is a representative of only a particular province in Pakistan but here the use of expression all big cities is inclusive and it does not limit his vision that he is going to hold rallies to liberate the people and to enlighten the people in any particular province of Pakistan. The expression all big cities can be taken as a metaphor of each nook and corner of all the big cities of four provinces of Pakistan. So, the headline under analysis on one hand uses idiomatic expressions in the form of to hold. The use of expression to hold is infinite which implies that the process initiated by Imran Khan in the form of holding rallies in different parts of the country will continue forever and there is no limit of the initiative taken by Imran Khan. Moreover, this particular newspaper has used the word Imran instead of using his full name Imran Khan which implies a degree of solidarity between the ideological group of the newspaper and Imran. The implications of the headline under discussion are that actor mentioned in the headline is religiously involved in liberating the people from the undue suppression of the government and he is willing to go to any length to offer his services to enlighten the general masses. Here, it is to be assumed that Imran is taking politics as a religious obligation and equally considers it his duty like a monk or religious head to lead the people to the right path. For this purpose, he presupposes (hold rallies) about rallies in all big cities (categorization) to liberate the people away from the clutches of ruling parties which are kept hidden in the headline deliberately. In this way by employing discursive techniques (as mentioned above) actor (Imran) is being positioned positively through print media discourse. So, as far as the use of lexicalization is concerned, the use of different ideological spins are concerned, the use of present tense is concerned and the use of idiomatic expression is concerned, all these linguistic spins combine together to convey Imran's determination and his intensity of feelings in enlightening his nation and people to liberate themselves from the undue political bondage of certain political parties. This is how the use of discursive technique by this newspaper ingroups Imran as a sincere and devoted leader and outgroups the other political parties by representing them negatively. It is also one of the 
prominent features of print media headlines that sometimes identity is concealed deliberately. This is how the concept of said verses unsaid is played up. In this headline, the said is Imran has been represented as a determined and sincere political leader who has assumed that it is his religious obligation to liberate the people of his country and to lead them towards right direction in order to provide justice to the deprived people. So, this is how Imran has been fore grounded by deliberately back grounding all the political parties of the country. So, this is how different discursive techniques are employed by print media group to represent a person or group positively and another person or group negatively.

\section{H.N1: Imran Khan steals Punjab's heart $\left(29^{\text {th }}\right.$ September 2014)}

Above mentioned headline was published in "The Daily Nation" carrying "political" theme. To disseminate political ideology, the encoder of the headline used the following discursive techniques:

Actor: Imran Khan

Hyperbole: steals

Metaphor: Punjab's heart

Personification: Punjab's heart

Punctuation:'

As far as the discursive techniques used in this specific headline are concerned, Imran's political struggle has been delimited only to Punjab's heart. Here, Punjab has been represented metaphorically. If somebody is capable of stealing heart, what remains behind, in this headline, Punjab has been given the central importance. Heart is a vital part of human body and it almost controls all the activities of the human body. Same is the case with Punjab. So, here, the use of apostrophe (') in Punjab's heart implies that Lahore is the centre of Punjab and if somebody wants to capture Punjab, he or she must be in a position to hold control in Punjab. The political implications can be there because in Punjab there are maximum number of seats wither in national assembly or of provincial assembly. If we analyse the headline placing it into discourse historical perspective proposed by Wodak (1997), it will be clear that in the past it has been that a party who is capable of winning maximum seats in Punjab has been the ruler of the country. It has also been a kind of game between different political parties that they have been conspiring with other political parties how to rule other parts of the country by capturing Punjab. Moreover, the use of lexicalization in the form of steals is there. The lexical item steals carry different connotations. Most often it is obvious that words carry their meaning in context. If we put the word steals out of context it carries negative connotations i.e. one who gets something by using left handed 
means. When the word is placed in context i.e. steals heart, and the equivalent in Urdu is dil churana and it is often said that it is better to rule the mind and heart than ruling the body. So, this headline implies that Imran has got so much popularity among the masses that his political ideology has been able to go deeper into the hearts of the people and especially of the people of Punjab. This is how it has been presupposed that his political ideology has got currency among the masses and now he can claim that he has stolen the hearts of people. Again, this expression is metaphorical, and it shows the relationship between the name giver and the named. So, here Imran has been represented as a popular leader who has got a very impressive rhetoric style. His rhetoric style, his political ideology and the cause he has been so far struggling finally have impressed the people. Finally, people have come to know that whatever he has been demanding so far is right. It means that if Imran, who is not at the moment the ruler of Punjab, is capable of stealing the heart of Punjab, it positions Imran belonging to in-group and a popular leader and his ideology as more beneficial ideology for the people and it invisibly outgroups the ruling party at the moment in Punjab because if he without having maximum seats in Punjab is capable of stealing the heart (Lahore), the time is not far when his ideology will dominate everywhere and he will be in a position to have a maximum acceptance as he has been given here in Lahore. Moreover, the use of full name Imran Khan implies a kind of distancing and the concept of formality between the ideological controlling group of this certain media group and Imran Khan. Moreover, the use of personification is there. The use of apostrophe (Punjab's heart) associates Punjab with living being or heart means Lahore. Here, Lahore has been represented as a living being and perhaps it has been able to control the country. The implicit ideology is that if Imran Khan has stolen the heart, the time is not far when his political ideology will be prevailing everywhere in the country. The use of word Khan also implies that not only his ideology is popular there in Khyber Pakhtunkha rather Khan's ideology is prevailing everywhere in the country. According to the IRI survey quoted in Tribune (2013), close to the previous elections, PML-N is supposed to have remained the most popular party in Punjab so far. Moreover, 'Heart' can have two implications; one that since Lahore is considered the heart of Punjab, there is also a hidden competition being created using word 'Punjab' instead of the one (all big cities) used by the 'The Daily Dawn.' In this way print media discourses highlight the concept of US vs THEM (Othering). Imran is shown as a popular leader, ruling the hearts of the people of Punjab province. Hegemonic power is there as general consent is won by stealing or capturing. Concept of centre or margin is there. If Lahore is heart it employs that Punjab is nothing without heart.

Trew (1979, p.155) aimed at isolating ideology in discourse and showing how ideology and ideological processes are manifested as systems of linguistic 
characteristics and processes. In "The Daily Dawn" Imran Khan is represented in different way whereas in "The Daily Nation" Imran Khan is represented in a competitive mood with the help of different discursive techniques. "The Daily Dawn" takes a straight and non-controversial statement whereas "The Daily Nation" takes a statement based on paradox and it is controversial too. "The Daily Dawn" and "The Daily Nation" both reflect political ideology but used different discursive techniques to disseminate the desired ideology as given below:

\section{The Daily Dawn The Daily Nation}

Actor Actor

Categorization Hyperbole

Lexicalization Metaphor

Presupposition Personification

Preposition Punctuation

Hence, difference in ideological representation is there in the print media about same event in two different English newspaper headlines because both belong to two different ideological groups. In this regard, it can be said that print media discourses are best site for ideological investment for creating the competitive ideology of 'Us' and 'Them' with the help of different discursive techniques.

\section{H.D2: Govt., army urged to make long term strategy to curb terrorism $\left(10^{\text {th }}\right.$ August 2014)}

The above mentioned headline is taken from "The Daily Dawn". The headline is also about the theme of politics related to solidarity. The main theme of the headline is to crush terrorism. Following discursive techniques have been used in the headline:

Actor: Govt., army

Evidentiality: long-term strategy

Lexicalization: urged

Polarization curb terrorism

Preposition to

Punctuation,

The two main pillars of nation (Govt., army) have been represented as actors in the headline. This indicates that government and army, both agree and are on the same page about this national issue. Discursive technique of polarization (curb terrorism) is used in this headline to indicate positive attitude of the both parties of the state, 
who are acting as active actors to curb terrorism. Lexical item "urged" indicates their positive attitude toward the national issue of terrorism as Merriam Webster dictionary (2015) defines "Urge" as: "To try to persuade (someone) in a serious way to do something". It implies the degree of seriousness on the part of Govt. and army to crush the evil of terrorism. It also implies a sense of oneness between government and army. This newspaper acting as a prism is disseminating the political ideology that the present political government is fully backed by army and vice versa. Evidentiality (long-term strategy) is used to make people believe about the seriousness of the actor (govt., army).

\section{H.N2: Conspirators to be defeated at every cost: PM (11 ${ }^{\text {th }}$ August 2014)}

The above stated headline was published in "The Daily Nation" carrying the theme of politics concerning nationalism. The following different discursive techniques are used in the headline:

Authority: PM

Evidentiality: at every cost

Polarization: to be defeated

Metaphor: conspirators

Preposition:

Punctuation:

Preposition (to) and punctuation mark in the form of colon (:) have also been used. Words used in the above stated headline are mouthpiece of head of the state (PM) and he is determined to defeat the conspirators. In the headline conspirators are "out grouped" and belong to "them". The word "conspirators" refers to the people who are engaged in conspiracy against government and state. Positive attributes are given to the "PM" as he will defeat the conspirators and "PM" belongs to "US". The use of ':' as punctuation mark implies that the sole aim of the PM is to crush conspiracy at any cost. Moreover, the use of phrase 'at every cost' implies the degree of determination on the part of PM or ruling party to bring peace in the country. Passivizing is another significant discursive technique to be employed for the positive self and negative other representation i.e. 'to be defeated'. The use of adjective 'conspirators' indirectly illustrates the conspiracy theory as it is usually believed that an unpleasant event or situation is a result of a secret plan made by powerful group. Dijk (1988) opines that discursivity is an important means of positioning the people as belonging to in-group or out-group. PM and his party are being rendered more visible at the cost of conspirators. Moreover, the use of phrase 'at every cost' implies the gravity of the situation caused by conspirators and at the same time degree of involvement in crushing out conspiracy theory on the part of 
PM party. Media groups work for the propagation of ideology of the powerful, the elite, and the state with the help of discursive techniques. Media discourses "contribute to reproducing social relations of domination and exploitation" (Fairclough 1995, p. 44). In above mentioned headlines both the newspapers have used different discursive techniques (as mentioned above) to disseminate the desired ideology any in the minds of target readers to create in-group and outgroup relations. In one headline govt. is shown with allies (Govt., army) and in one the other alone (PM). The Daily Nation uses passive voice to make conspirators out-group and for firmness in the headline and The Daily Dawn uses active voice. These are different techniques by which the media groups produce power relation with the help of different discursive techniques. "The Daily Dawn" and "The Daily Nation" both reflect the theme of politics but have used different discursive techniques to disseminate the desired ideology as given below:

\section{The Daily Dawn The Daily Nation}

Actor: Authority

Evidentiality: Evidentiality

Lexicalization: Metaphor

Polarization:

Abbreviation Preposition

Preposition and Punctuation

The above mentioned table elaborates clearly that both newspapers have used different discursive techniques to disseminate desired ideological themes. This is how print media discourses represent same political agenda differently by manipulating political discourses.

\section{Graphical aspects of the Research Findings of The Daily Dawn and The Daily}

\section{Nation}

Graph 1 lists the quantitative content analysis results of all the related news headlines reported by The Daily Dawn. It can readily be seen that the newspaper is more inclined towards using strategies including lexicalization, preposition, punctuation, categorization and actor description. Its inclination towards the usage of hyperbole, metaphors, personification and Polarization was not evident in the selected headlines. The remaining strategies were seen to be used only once in the 4 headlines analysed. 


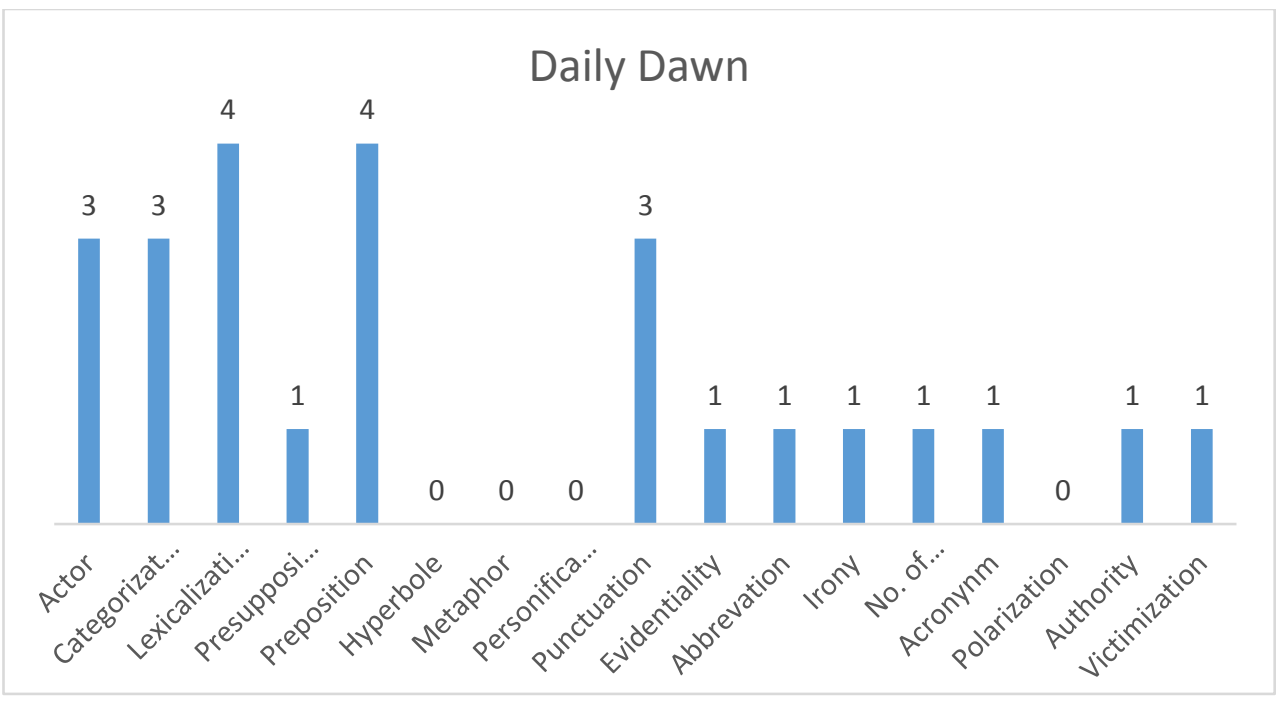

Graph 1. Discursive Strategies used by The Daily Dawn

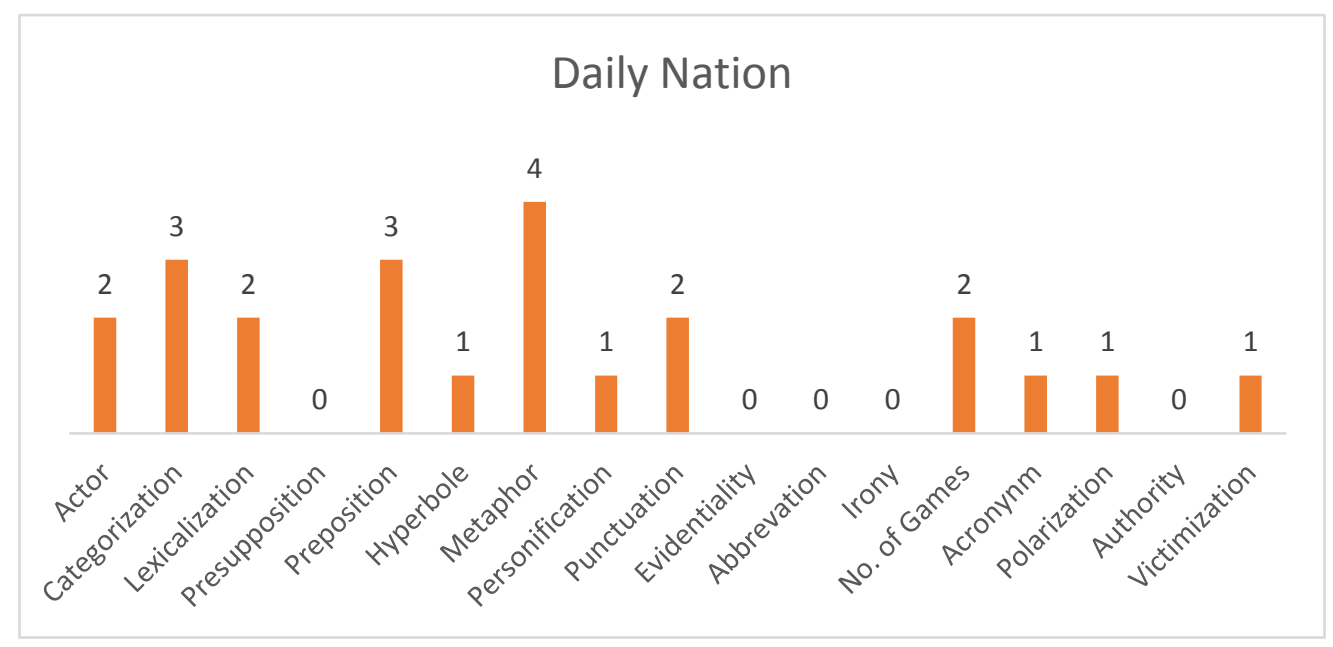

Graph 2. Discursive strategies used by The Daily Nation

The Graph 2 illustrates the use of discursive strategies in The Daily Nation for the propagation of ideologies in relevance to the headlines under discussion. This newspaper uses metaphors as its popular tool to disseminate ideologies through headlines. Moreover, categorization and the use of preposition are also seen as being repeated in the headlines. Strategies including presupposition, evidentiality, abbreviations, authority and irony have not been used in the headlines under study. 


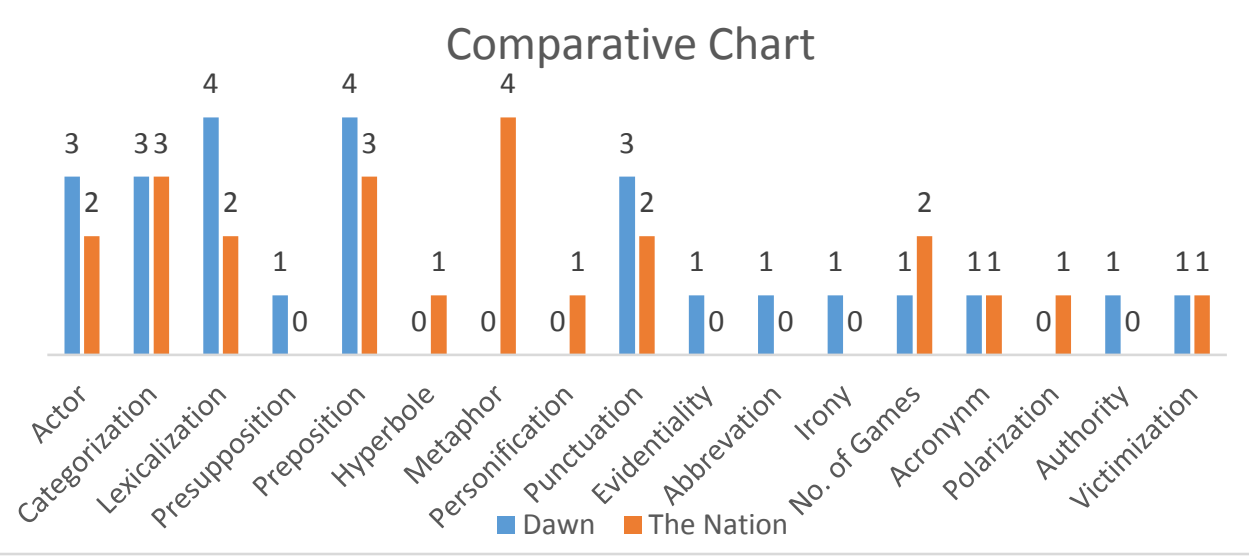

Graph 3. Comparative chart of the two Newspapers, The Daily Dawn and The Daily Nation, displaying the use of Discursive Strategies in similar news headlines.

Graph 3 shows a comparison of the two newspapers employing discursive strategies in similar headlines, containing the same information. It is evident from the table above, that The Daily Dawn heavily relies upon the discursive strategies in order to propagate ideologies in its target readers. Actor description, lexicalization, categorization, preposition, punctuation and victimization have been the most repeated strategies in headlines by The Daily Dawn while The Daily Nation is observed to employ categorization, preposition and metaphors as its most repeated strategies for headlines.

\section{Conclusion}

The findings of the research highlight that the use of discursive techniques is a significant feature in the dissemination of different ideologies differently to the target readership. It is also revealed that these two different newspapers employ different discursive moves to propagate desired ideologies to their target readership. At the same time, it highlights that the use of discursivity in the headlines is not ideology free as each newspaper employs insidious weapon of language to include certain ideological groups as "in group" and certain others as "out-group". This study has proved that use of discursive techniques can disseminate underlying ideologies by reporting and reshaping the headlines in different ways to shape or reshape the mindset of the desired readership. Even the same event can be manipulated in different ways by different media groups with the help of discursive techniques. 


\section{References}

Abastado, C. (1980). Messages de medias. Paris: Cedic.

Ahmad, Z. (2013, January 28). IRI survey: PML-N's popularity on the rise. Retrieved from https://tribune.com.pk/story/499599/iri-survey-pml-ns-popularity-on-the-rise/

Alfangca, K. Z. (2015). The Transitivity elements and ideology: a newspaper headlines analysis on MH370 flight accident. Retrieved from htt://repository.wima.ac.id/4884/

Bonyadi, A., \& Samuel, M. (2013). Headlines in Newspaper Editorials: A Contrastive Study. SAGE Open, 3(4), 1-10.

Fairclough, N. (1992). Discourse and social change. Cambridge: Polity Press.

Fairclough, N. (1995). Media Discourse. Cambridge: Longman.

Fairclough, N., \& Wodak, R. (1997). Critical Discourse Analysis. In T. van Dijk (Ed.) Discourse Studies A Multidisciplinary Introduction, 2, 258-284. London: Sage.

Fang, Y. J. (2001). Reporting the same events? A critical analysis of Chinese print news media texts. Discourse \& Society, 12(5), 585-613.

Fowler, R. (1991). Language in the news: Discourse and ideology in the press. London: Routledge.

Gopang, I. B. (2015). English speaking anxiety: A study of undergraduate students of English. International Researcher, 4(1), 54-61.

Javed, S. (2011). A critical Discourse Analysis of The News Headlines of Budget of Pakistan FY 2011-2012. Interdisciplinary Journal of Contemporary Research in Business, 29(4), 635-652.

Ogilvy, D. (2011). Confessions of an Advertising Man. New York: Ballantine Books.

Phillips, N., Lawrence, T., \& Hardy, C. (2004). Discourse and Institutions. Academy of Management Review, 29(4), 635- 52.

Rahman, T. (1996). Language and Politics in Pakistan. Karachi: Oxford University.

Rahman, T. (2007). The Role of English in Pakistan With Special Reference to Tolerance and Militancy in Language Policy, Culture, and Identity in Asian Contexts. Bulletin of Education and Research, 40(1), 39-56.

Sajid, A. (2012). Representation of Islam: A Study into Discourse of Pakistani and the Western Newspapers. Multan: Unpublished Ph.D. Thesis, BZU.

Trew, T. (1979). Theory and Ideology at Work. In R. Fowler, R. Hodge, G. Kress, \& T. Trew (Eds.), Language and Control (pp. 94-116.). London: Routledge and Kegan Paul.

Ulum, G. (2016). Newspaper Ideology: a critical discourse analysis of news headlines on Syrian refugees in published newspapers. Retrieved April 27, 2017, from www.Reseacrhgate.net

Van Dijk, T. (1988). News as Discourse. New Jersey: Erlbaum.

Van Dijk, T. (2006). Politics, Ideology, and Discourse. Retrieved 10 09, 2019, from http://www.discourses.org/OldArticles/Politics, \%20Ideology\%20and\%20Discourse. pdf

Van Dijk, T. A. (1991). Racism and the Press. London: Routledge.

Van Dijk, T. A. (1998). Discourse as Structure and Process. London: Sage Publication.

Van Dijk, T. A. (2008). Discourse and context. A sociocognitive approach. Cambridge: Cambridge University Press.

Wodak, R. (1997). Disorders of discourse. London: Longman. 